\title{
Wear Analysis of Human Cornea in Keratoconus Disease
}

\author{
Hamid Zamanlou $^{1 *}$, Filiz Karabudak ${ }^{2}$ \\ ${ }^{1 *}$ Ataturk University, Faculty of Engineering, Departmant of Mechanichal engineering, Erzurum, Turkey, (ORCID: 0000-0002-9780-8924), \\ zamanloohamid@gmail.com \\ ${ }^{2}$ Gumushane University, Faculty of Engineering and Natural Science, Departmant of Mechanichal Engineering, Gumhushane, Turkey, (ORCID: rg/0000-0002-7365- \\ 0333), filizkarabudak@gumushane.edu.tr
}

(International Conference on Design, Research and Development- 15 - 18 Aralık 2021)

(DOI: 10.31590/ejosat.1039221)

ATIF/REFERENCE: Zamanlou, H. \& Karabudak, F. (2021). Wear Analysis of Human Cornea in Keratoconus Disease. European Journal of Science and Technology, (32), 312-317.

\begin{abstract}
The cornea is a transparent and curved tissue located at the front of the eye, specialized to focus light and protect the eye from external factors. The importance of the cornea in the structure of the eye and visual system is often overlooked because of its transparent nature. The cornea lacks the complex neurobiological structure of the retina and the dynamic nature of the lens, but despite this, it is unable to function properly without transparency in this organ of the eye. The complexity of the structure and function of the cornea, which makes it transparent, is a surprise that led us to examine one of the most important components of the visual system. The cornea is a vascular-free connective tissue that serves as the first barrier to the spread of infection to It acts inside the eyeball as well as the building block of the eye wall. Corneal transparency is due to several factors, including the structural anatomy and physiology of its cellular components.

Keratoconus is an eye condition in which the cornea deforms and protrudes forward in a cone shape. This change that occurs in the cornea causes the incoming light to be unable to focus in the visual field. The result is blurred and distorted vision.

There are also studies showing that eye rubbing can be effective in the onset and progression of the disease.

In this study, wear from eye rubbing in kerataconus disease was analyzed by means of finite elements. Deformation and stress analysis in the cornea were investigated. FEM can help to predict biomechanichal behavior of corna after kerataconus dises.

Due to the rubbing effect at the contact point, contact pressure, vonmises stress and wear reach their maximum value.
\end{abstract}

Keywords: Wear, Cornea, Finite Elements Methods

\section{Keratokonus Hastalığında İnsan Korneasının Aşınma Analizi}

$\ddot{O} \mathbf{z}$

Kornea, gözün ön kısmında bulunan, 1şı̆̆ı odaklamak ve gözü dış etkenlerden korumak için özelleşmiş şeffaf ve kavisli bir dokudur. Korneanın göz ve görme sistemi yapısındaki önemi, şeffaf yapısı nedeniyle çoğu zaman gözden kaçmaktadır. Kornea, retinanın karmaşık nörobiyolojik yapısından ve merceğin dinamik yapısından yoksundur, ancak buna rağmen, gözün bu organında şeffaflık olmadan düzgün bir şekilde çalışamaz. Korneanın şeffaf olmasını sağlayan yapı ve işlevinin karmaşıklı̆̆ı, görsel sistemin en önemli bileşenlerinden birini incelememize neden olan bir sürprizdir. Kornea, enfeksiyonun yayılmasının önündeki ilk bariyer görevi gören damarsız bir bağ dokusudur. Kornea şeffaflığı, hücresel bileşenlerinin yapısal anatomisi ve fizyolojisi dahil olmak üzere çeşitli faktörlerden kaynaklanmaktadır.

Keratokonus, korneanın deforme olduğu ve koni şeklinde öne çıktığı bir göz rahatsızlığıdır. Korneada meydana gelen bu değişiklik, gelen 1şığın görme alanında odaklanamamasına neden olur. Sonuç, bulanık ve çarpık görmedir.

Ayrıca göz ovuşturmanın hastalığın başlangıcında ve ilerlemesinde etkili olabileceğini gösteren çalışmalar da mevcuttur.

Bu çalışmada keratakonus hastalığında göz ovuşturma sonucu oluşan aşınma sonlu elemanlar yöntemiyle incelenmiştir. Korneada deformasyon ve stres analizi araştırılmıştır. SEY, keratakonus hastalığından sonra kornanın biyomekanik davranışını tahmin etmeye yardımcı olabilir.

kontakt noktasında ovuşturma etkisinden dolayı contact basınç, vonmises gerilme ve aşınma en ust değerine ulaşmaktadır

Anahtar Kelimeler: Aşınma, Kornea, Sonlu Elemanlar Yöntemi.

\footnotetext{
* Corresponding Author: zamanloohamid@gmail.com
} 


\section{Introduction}

Corneal tissue normally has five layers, called the outer layer into the epithelial layer, the Bowman layer, the stromal layer, the membranous membrane, and the endothelium, respectively. The lack of blood vessels makes this part of the eye transparent. Corneal abrasion occurs when the cells of the corneal epithelium, the cells of the outer layer, are damaged and removed from the surface of the cornea. There are several factors that contribute to corneal wear and tear. Using contact lenses for a long time, rubbing the eye after suspended particles such as dust enter the eye, Performing activities such as welding without glasses are among the most important causes of wear. If people do not pay any attention to corneal ulcers and scratches; Over time, the wound can penetrate other areas of the corneal tissue and destroy the retina once it enters the retina. Retinal cell necrosis causes blindness (Wang \& Chester, 2021).

The cornea and its structure are very important today from two perspectives and a lot of research is focused on it. A look at the symmetrical optical properties and the main refractive part of the eye, according to which all laser refractive correction treatments are focused on the cornea and depend on the optical properties of the cornea as well as the molecular structure and biomechanical properties of the cornea. (Kehrer \& Mosquera, 2021)

Keratoconus is a progressive disease of the cornea that generally affects both eyes. This condition causes the cornea (the outermost layer of the eye) to become thinner and deformed. The cornea is conical in shape, resulting in irregular myopia and astigmatism, leading to severe vision loss. The pathophysiology of the disease and how it develops and progresses is not well understood. One of the main factors in its development is genetic factors that seem to be multifactorial, although the molecular or genetic disorder is not known. Eye rubbing, use of hard lenses, or post-traumatic eye injury have also been reported as the reasens of kerataconus. Figure 1 shows the difference between normal cornea and keratoconic cornea.

Keratoconus is a treatable disease and when diagnosed in the early stages, before corneal transplantation. treatment is possible (Ertan \& Colin, 2007). Both surgical and non-surgical treatment methods is implemented. Depending on the condition of the cornea, there are also treatment options such as cross-linking and corneal rings. With the cross-linking operation, the progression of the disease can be stopped by affecting the collagen molecules and increasing the mechanics of the cornea with the help of Ultraviolet A (long-wave) rays and Riboflavin drops (Sandner, Spoerl, Kohlhaas, Unger, \& Pillunat, 2004).

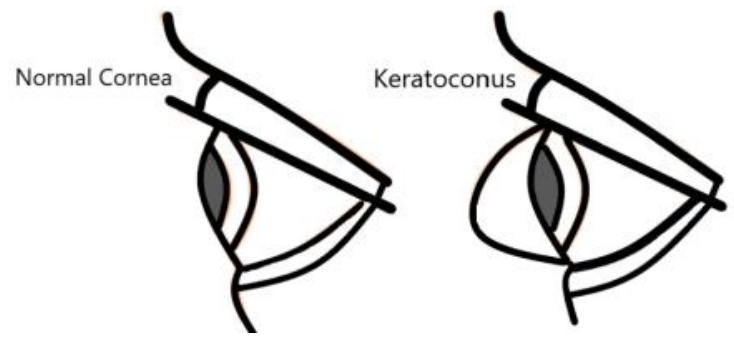

Figure 1. Normal Cornea vs Keratokonic
In the last few decades, finite element modeling has been used as an effective tool for modeling and simulating biomechanical engineering systems. The FEA is a computational tool for performing engineering analysis. The tool uses mesh generation methods to divide a complex problem into small elements and the software code of FEM algorithms. In FEM, it is possible to accurately display the place of bending or torsion of the structure and to detect how stresses and displacements are distributed. FEM software provides designers with many options for controlling the complexity of modeling and analyzing a system. In this way, the required level of accuracy and timing of calculations for most engineering problems can be managed. The finite element method makes it possible to build, modify and optimize designs before production begins.

Finite Element Modeling (FEM) is a computational technique that can be used to solve biomechanical engineering problems based on continuous mechanics theories. A FEM model can be simulated to Show the biomechanichal behavior of keratakonus cornea (Zamanlou \& Karabudak, 2021).

In this study beside the strain - stress distribution analysis of cornea across the rubing, wear were analysed by finite elements methods in the use of ANSYS program package.

\section{Material and Method}

\subsection{Finite Elements Modeling}

In this study, a three-dimensional model containing the details of the tidal wear system was prepared with the ANSYS package program. SOLID 185 is used as the element type and it is an element used in modeling of 3D structures. Nine nodes with three degrees of freedom and orthotropic material properties can be defined. The element has plasticity, hyperelasticity, stress hardening, creep, high deformation and high strain capacity. When used in irregular areas, it is advantageous to take prismatic, tetrahedral and pyramid shapes. TARGE170 and CONTA174 elements with "surface to surface" feature were used to model the contact zone. Finite Elements Model of cornea shown in Figure 2.

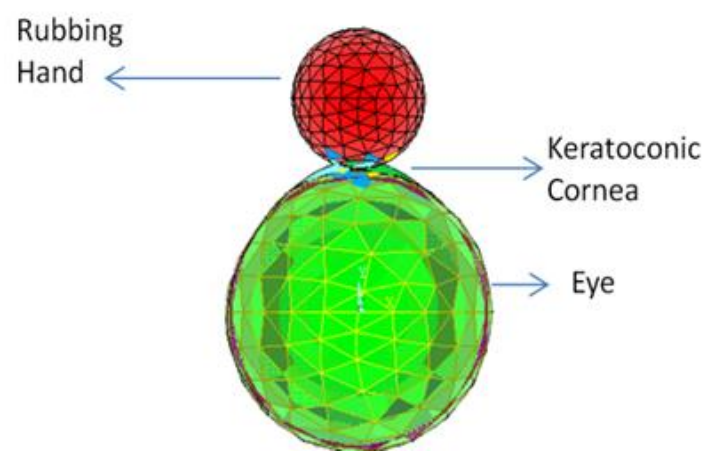

Figure 2. FEM model of Kerataconic kornea in the contact point of rubbing hand

Dimensions and mechanichal properties of kerataconic cornea used for FEM are as shown in table 1. 
Table 1. Dimensions of cornea used for FEM

\begin{tabular}{l|c}
\hline Cornea & Value \\
\hline Thickness & $0.45 \mathrm{~mm}$ \\
\hline Diameter & $11.9 \mathrm{~mm}$ \\
\hline $\begin{array}{l}\text { Anterior corneal } \\
\text { curvature }\end{array}$ & $7.7 \mathrm{~mm}$ \\
\hline $\begin{array}{l}\text { Posterior corneal } \\
\text { curvature }\end{array}$ & $6.3 \mathrm{~mm}$ \\
\hline Kerataconic Diameter & $1.5 \mathrm{~mm}$ \\
\hline $\begin{array}{l}\text { Young Modulus of } \\
\text { cornea }\end{array}$ & $0.4 \mathrm{Mpa}$ \\
\hline Poisson'a rtio of cornea & 0.42 \\
\hline Density of Cornea & $1400 \mathrm{Kg} / \mathrm{m}^{3}$ \\
\hline Cornea hardness & $0.003 \mathrm{mpa}$ \\
\hline
\end{tabular}

\subsubsection{Wear Modeling}

The finite element method is an effective tool for contact problems. This method allows to describe the relationship of elements with a real geometry, physical and mechanical properties of materials, and mixed boundary conditions. These types of problems are commonly referred to as contact problems. Contact between elements is one of the load transfer methods. Such a charge transfer technique depends on the nature of the relationship between two or more contact surfaces. It is quite difficult to directly examine the contact state and measure them. There are two boundary states in contact problems. The first is the contact surface and the other is the target surface. The chosen surface-to-

In this study, a three-dimensional model containing the details of the tidal wear system was prepared with the ANSYS

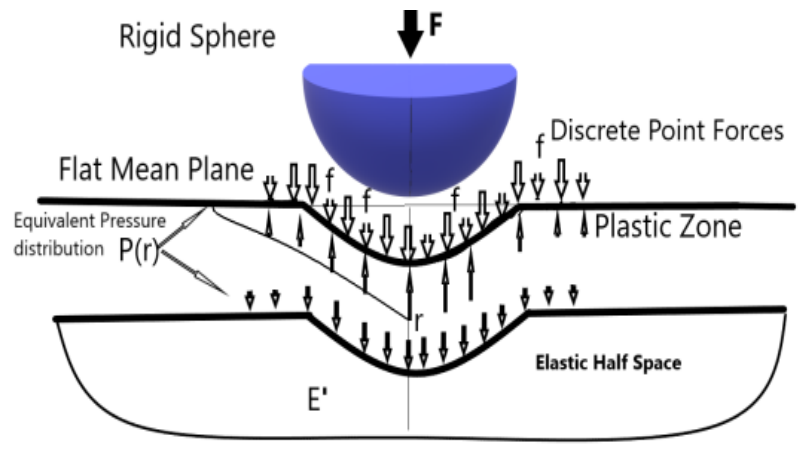

Figure 3. Contact Region

\section{Results and Discussion}

In order to model the structure of the keratoconus cornea, a 3-dimensional finite element model was created in accordance with the contact theory.

Contct pressure of analaysed model shown in figure 4. Level (A) has the minimum value of contact presure and level (I) has the maximum value. In the first contact point the level is the highest as $2.1621 \mathrm{~N}$. surface contact situation is suitable for this problem. values with precision. The contact problem is complex because the behavior of the elements that generate the contact stresses depends on the material properties.

The Archard wear model simulates a gradually increasing loss of material from the contact surface (Thompson \& Thompson, 2006). During wear, $\boldsymbol{w}$ estimates the volume loss, which is proportional to the pressure at the contact surface, the sliding speed, and the contact surface. Wear occurs in the opposite direction of the contact surface.

$$
\mathrm{W}=\frac{K}{H} P^{m} v_{r e l}^{n}
$$

Here, $\mathrm{K}$ is the wear coefficient, $\mathrm{H}$ is the material hardness, $\mathrm{P}$ is the contact pressure, $\mathrm{m}$ is the pressure exponent, $v_{r e l}$ is shear velocity and $\mathrm{n}$ is the velocity exponent. Contact NODEs move to new positions, changing contact variables. The underlying continuity elements also lose material and thus wear is simulated.

In the ANSYS package program, the archard wear model is specified by entering the constants $\mathrm{C} 1, \mathrm{C} 2, \mathrm{C} 3$, and $\mathrm{C} 4$ in the TBDATA command. These constants are defined as the wear coefficient $(\mathrm{K})$, material hardness $(\mathrm{H})$, contact pressure $(\mathrm{m})$, and shear rate exponent (n). Shematic view of contact region shown in figure 3 (Bahrami, Culham, Yovanovich, \& Schneider, 2004).

It is possible to obtain the pressure exponent from the general pressure distribution in the contact area:

$$
\mathrm{\gamma}=\frac{P_{0}}{P_{0} \cdot H}\left(\frac{a_{L}}{a_{H}}\right)^{2}-1
$$

package program. In the finite element analysis, first, the material properties are defined. The nonlinear properties of the materials were also defined as bilinear (bilinear) (bilinear isotropic hardening - yield load and tangent or modulus of plasticity) and all material properties were considered as elasto - plastic and isotropic. hand rub is accepted as 5 N. In FEM, 156 cycles corresponding to 20 meters were considered as the total sliding distance

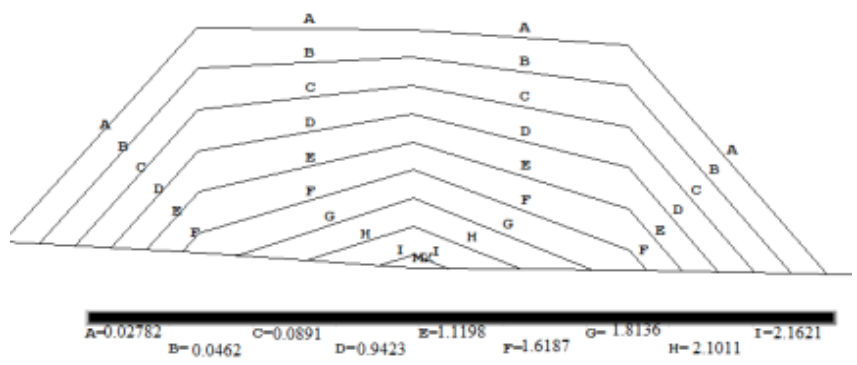

Figure 4. Contact Pressure

In the case of elements subjected to normal and shear stresses, it is possible to use the von Mises stress criterion to determine whether the object has reached the yield point or not. In finite element software, in stress analysis, von Mises stress is usually used to judge the stresses on the material, and this value is compared with the yield stress of the material. Figure 5 shows the Von Mises stress distribution of contact area. It should not be forgotten that the mechanical behavior of materials also occurs in accordance with the two laws of thermodynamics. 


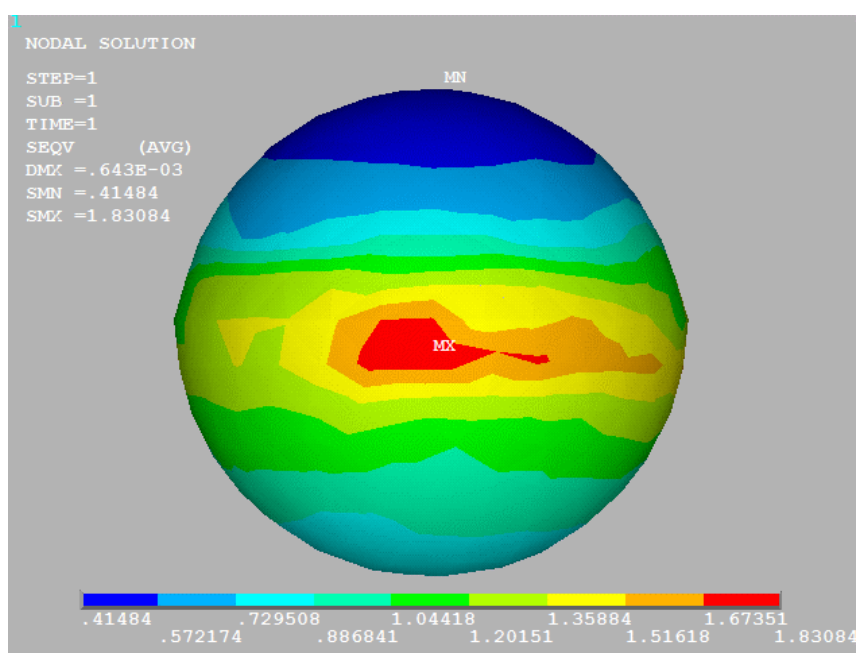

Figure 5. Von Mises stress

Wear levels in contact region shown in figure 6. A has the haighest level of wear and I has the lovest level. Wear value changes depending on time, frequency and load. starting point of contact appears in region A. Wavy wear can take many forms and, in most cases, no satisfactory explanation for the occurrence of wear can be found. In addition, images with different causes can be encountered at the same time. Classification of wave wear types is generally done in different ways according to wavelengths.

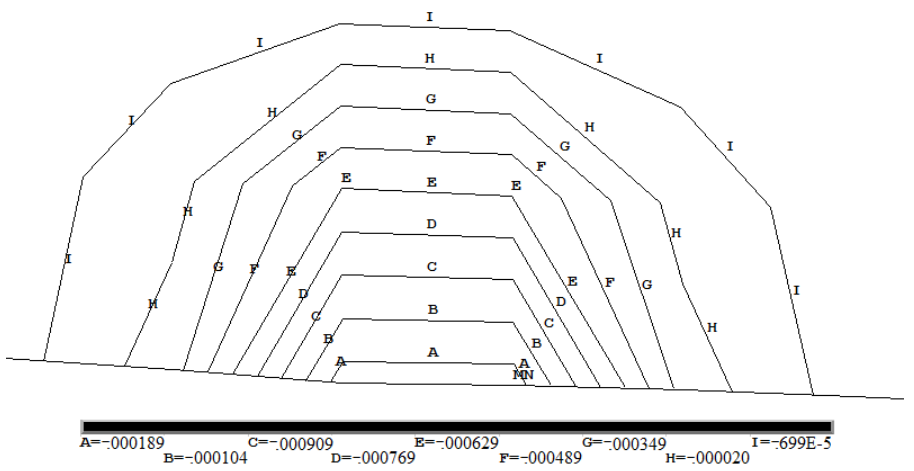

Figure 6. Wear levels in contact region

Figure 7 is about the YZ shear stress level in cornea. Shear stress is a component of stress that is applied to the cross section of an object. Shear stress is caused by the force vector perpendicular to the normal cross-sectional vector.

As seen in all figures, it is seen that the contact distances and contact stresses obtained from the finite element method analysis (ANSYS) results presented in the study are very close to the results in the literature. It is seen in all figures that the results are compatible in terms of the dimensionless stresses obtained from the finite element and analytical solution.

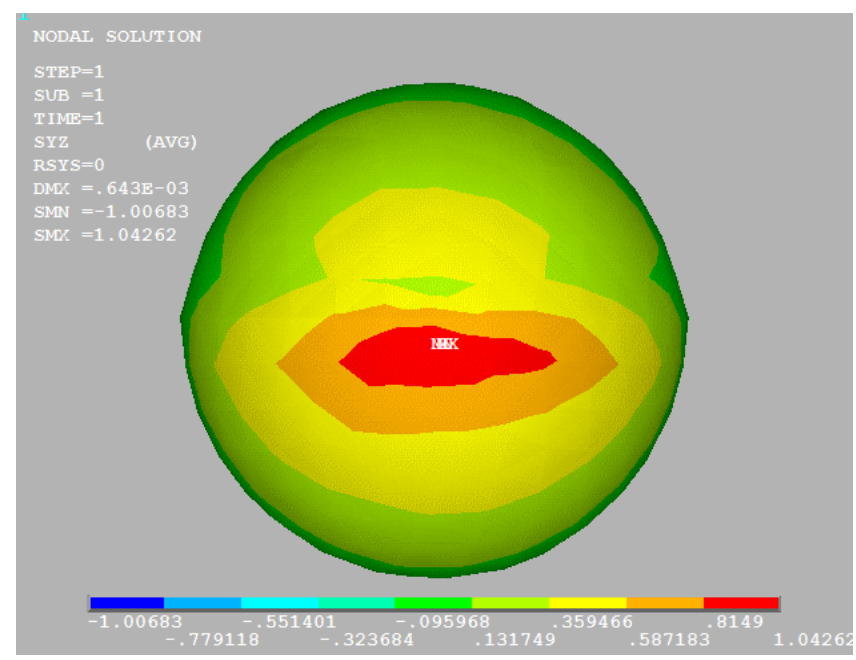

Figure 7. YZ Shear Stress Level

Total Mechanichal strain Shown in Figure 8. it shows deformation representing the relative displacment between particels and cornea body. the regions that appear red show more maximum values.

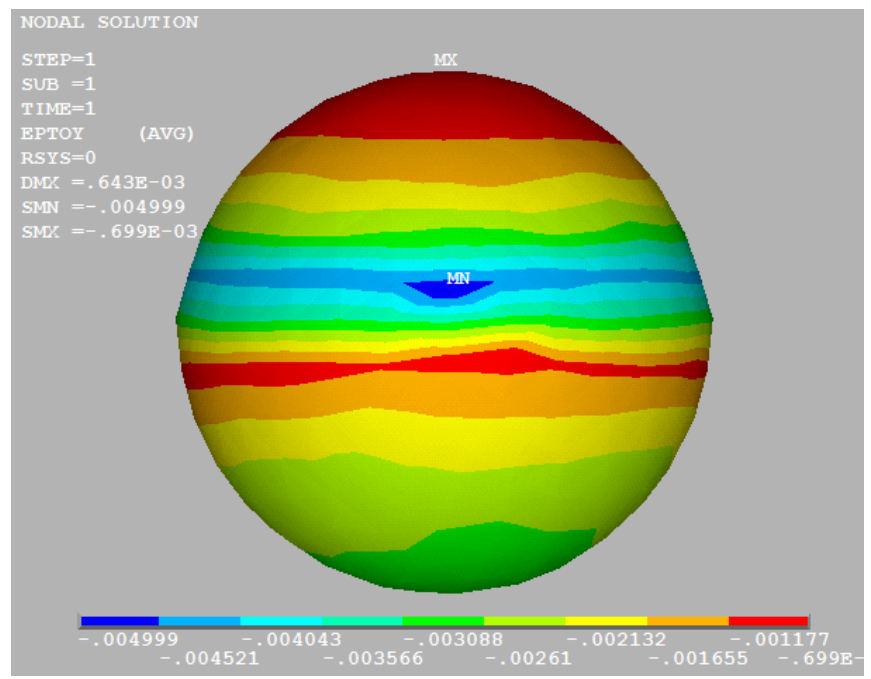

Figure 8. Total Mechanichal Strain

\section{Conclusions and Recommendations}

A corneal wear is a hole, scratch, or scrape on the cornea, the clear area of the eye that covers the pupil and iris. Wear are very common injuries that can occur as a result of irritation or irritation of the eyes, dirt or other particles from contact lens use. A damaged cornea can cause the eye to be light sensitive, red, itchy, and produce excessive tears. Most injuries heal on their own within a few days without treatment, but a severe corneal abrasion may require emergency medical care to remove foreign particles and prevent infection.

The finite element method is an important aid in modeling difficult irregular structures, it provides convenience in the definition of load cases, it provides serious convenience in modeling because it analyzes each element of the structure one by one, different node situations can be easily resolved, it provides 
an economic contribution because it is easy to change the model, dynamic effects may be included. With this method, large deformations and non-linear behavior in materials can be controlled.

Wear is an undesirable situation that leads to damage in any system. The model is close to real conditions, but the Arrhenius effect is not taken into account (Jensen, 1985). load and frequency increase may increase the contact pressure and thus the wear rate. The rubbing force may lead to two body wear and some times three body wear whith the help of grains. Since the surface of the kerataconus cornea is more convex, wear is more effective. Surface wear is a nonlinear specific load function, and the effect of the load is much more enhanced for small non-wavy contact surfaces. The waviness greatly reduces the non-linearity of this relationship. FEM can be used as a tool for investigating the biomechanical behavior of the cornea. In the future study FEM can help to predict corneal dises. Finite Elemnts Analysis has been used to provide a better understanding of corneal bio mechanics in a variety of settings. This can be a non-invasive and predictive method to evaluate the function of the cornea and to study related diseases. FEM can be used in clinical practice to evaluate corneal disorders and provide possible treatments. FEA can predict preand post-corneal responses to refractive surgery and can be used as a patient-specific simulation tool in clinical applications for surgical methods ( Nejad, Foster, \& Gongal , 2014). Using the results of statistical methods together with the three-dimensional modeling results of the study will be more supportive and guiding for field experts and researchers.

The only treatment currently available to prevent worsening of keratoconus is collagen cross-linking. Cross-linking of the eye strengthens and stabilizes the cornea by creating a link between the collagen fibers in the cornea. In cross-linking, liquid riboflavin (vitamin B2) is first applied to the surface of the eye and then the eye is exposed to ultraviolet light.

Due to the increase in corneal resistance after cross-linking, the amount of eye resistance to wear will increase and the deformations in the cornea will be minimized.

\section{References}

Wang, S., \& Chester, S. A. (2021). Multi-physics modeling and finite element formulation of corneal UV cross-linking. Biomechanics and Modeling in Mechanobiology, 1-18.

Birkenfeld, J. S., Curatolo, A., Eliasy, A., Martinez-Enriquez, E., Varea, A., Ramos, A. M. G., ... \& Marcos, S. (2022). Corneal biomechanical parameters from keratoconus patients using cross-meridian air-puff deformation optical coherence tomography and finite element modeling

Isaacson, A., Swioklo, S., \& Connon, C. J. (2018). 3D bioprinting of a corneal stroma equivalent. Experimental eye research, 173, 188-193.

Elsheikh, A. (2010). Finite element modeling of corneal biomechanical behavior. Journal of Refractive Surgery, 26(4), 289-300.

Pinsky, P. M., \& Datye, D. V. (1991). A microstructurally-based finite element model of the incised human cornea. Journal of biomechanics, 24(10), 907-922.

Roy, A. S., \& Dupps, W. J. (2009). Effects of altered corneal stiffness on native and postoperative LASIK corneal biomechanical behavior: a whole-eye finite element analysis. Journal of refractive surgery, 25(10), 875-887.
Spevak, L. F., \& Babailov, N. A. (2020, December). A finite element model of the stress-strain state of the human cornea. In AIP Conference Proceedings (Vol. 2315, No. 1, p. 040038). AIP Publishing LLC.

Birkenfeld, J. S., Curatolo, A., Eliasy, A., Martinez-Enriquez, E., Varea, A., Ramos, A. M. G., \& Marcos, S. (2022). Corneal biomechanical parameters from keratoconus patients using cross-meridian air-puff deformation optical coherence tomography and finite element modeling.

Huang, L., Shen, M., Liu, T., Zhang, Y., \& Wang, Y. (2020). Inverse solution of corneal material parameters based on noncontact tonometry: A comparative study of different constitutive models. Journal of Biomechanics, 112, 110055.

Karimi, A., Meimani, N., Razaghi, R., Rahmati, S. M., Jadidi, K., \& Rostami, M. (2018). Biomechanics of the healthy and keratoconic corneas: a combination of the clinical data, finite element analysis, and artificial neural network. Current pharmaceutical design, 24(37), 4474-4483.

Velázquez Blázquez, J. S., Cavas Martínez, F., Bolarín Guillén, J. M., \& Alió Sanz, J. L. (2020). Comparison of corneal morphologic parameters and high order aberrations in keratoconus and normal eyes.

Perone, J. M., Conart, J. B., Bertaux, P. J., Sujet-Perone, N., Ouamara, N., Sot, M., \& Henry, J. J. (2017). Mechanical modeling of a keratoconic cornea. Cornea, 36(10), 12631266.

Zamanlou, H., \& Karabudak, F. (2021). Comparison of Mechanical Fatigue for Human Cornea before and after CCL in. 22. Ulusal Mekanik Kongresine (p. 250). TUMTMK.

Vijay, R., Kumar, V. A., Sadiq, A., \& Pillai, R. R. (2021, February). Numerical Analysis of Wear Characteristics of Zirconia Coated Aluminum 6061 Alloy. In IOP Conference Series: Materials Science and Engineering (Vol. 1059, No. 1, p. 012020). IOP Publishing.

Thompson, J. M., \& Thompson, M. K. (2006, January). A Proposal for the Calculation of Wear. In Proceedings Of The 2006 International Ansys Users Conference \& Exhibition, Pittsburgh, Pa.

Bahrami, M., Culham, J. R., Yovanovich, M. M., \& Schneider, G. E. (2004). Thermal contact resistance of nonconforming rough surfaces, part 1: contact mechanics model. Journal of Thermophysics and Heat Transfer, 18(2), 209-217.

Jensen, F. (1985). Activation energies and the Arrhenius equation. Quality and Reliability Engineering International, 1(1), 1317.

Nejad, T. M., Foster, C., \& Gongal, D. (2014). Finite element modelling of cornea mechanics: a review. Arquivos brasileiros de oftalmologia, 77, 60-65.

Kehrer, T., \& Mosquera, S. A. (2021). A simple cornea deformation model. Advanced Optical Technologies.

Ertan, A., \& Colin, J. (2007). Intracorneal rings for keratoconus and keratectasia. Journal of Cataract \& Refractive Surgery, 33(7), 1303-1314.

Sandner, D., Spoerl, E., Kohlhaas, M., Unger, G., \& Pillunat, L. E. (2004). Collagen Crosslinking by Combined Riboflavin/Ultraviolet-A (UVA) Treatment can stop the progression of Keratoconus. Investigative Ophthalmology \& Visual Science, 45(13), 2887-2887.

Stachura, J., Mlyniuk, P., Bloch, W., Jimenez-Villar, A., Grulkowski, I., \& Kaluzny, B. J. (2021). Shape of the anterior surface of the cornea after extended wear of silicone hydrogel soft contact lenses. Ophthalmic and Physiological Optics, 41(4), 683-690. 
Del Castillo, L. F., Ramírez-Calderón, J. G., Del Castillo, R. M., Aguilella-Arzo, M., \& Compañ, V. (2020). Corneal relaxation time estimation as a function of tear oxygen tension in human cornea during contact lens wear. Journal of Biomedical Materials Research Part B: Applied Biomaterials, 108(1), 1421.

Zhang, J., Li, J., Li, X., Li, F., \& Wang, T. (2020). Redistribution of the corneal epithelium after overnight wear of orthokeratology contact lenses for myopia reduction. Contact Lens and Anterior Eye, 43(3), 232-237.

Moran, S., Gomez, L., Zuber, K., \& Gatinel, D. (2020). A casecontrol study of keratoconus risk factors. Cornea, 39(6), 697701.

Mathan, J. J., Gokul, A., Simkin, S. K., Meyer, J. J., Patel, D. V., \& McGhee, C. N. (2020). Topographic screening reveals keratoconus to be extremely common in Down syndrome. Clinical \& Experimental Ophthalmology, 48(9), 1160-1167.

Bhat, B., Poojary, R. G., Prabhu, G., \& Ve, R. S. (2021). FEM Based Study for Estimation of Applanation Force and Influence of Intraocular Pressure on Tonometry.

GZAIEL, M., TRIKI, E., BARKAOUI, A., \& CHAFRA, M. Finite element modeling of energy-state in combined puncture/cutting of soft material by a pointed blade. 